\title{
Resistance to new antiretrovirals (ETV, anti-integrases, entry inhibitors)
}

\author{
Francesca Ceccherini-Silberstein \\ From $16^{\text {th }}$ International Symposium on HIV and Emerging Infectious Diseases \\ Marseille, France. 24-26 March 2010
}

HIV is extremely variable and newly arisen variants may be rapidly selected upon drug pressure. New antivirals are available, new therapeutic options are at hand for all patients, either naïve or multiexperienced. Individualization is the hallmark of new approaches to antiretroviral therapies. Knowledge of drug resistance is important to guide clinicians in devising treatment regimens and to optimally preserve later treatment options for patients.

This presentation will focus on the new technologies, methodologies, models and research tools to enhance detection and interpretation of HIV-1 drug-resistance. Particular attention will be dedicated to the resistance to the new antivirals.

The development of the new second-generation NNRTI etravirine, which has a higher genetic barrier than the first-generation drugs, has led to new understanding of the complexity of NNRTI resistance. To date, 17 mutations have been identified as being associated with etravirine resistance and reduced virological response.

Integrase inhibitors are very potent drugs providing a great opportunity for clinicians, to construct new regimens for individuals with HIV infection resistant to all three traditional classes of antivirals. However, these drugs have a relatively low genetic barrier to resistance and thus require both the selection of an optimised backbone to ensure durable viral suppression and a clear understanding of their residual activity in a failing integrase regimen. Resistance tests able to sequence and detect mutations in integrase are crucial for their proper use in clinical practice.

Viral escape of entry inhibitors may occur through 'classic' viral resistance to the compounds, but also by usage of alternative cell co-receptors. To date the main focus of research on co-receptor antagonists has been

$$
\text { Department of Experimental Medicine, University of Rome Tor Vergata, }
$$$$
\text { Rome, Italy }
$$

on determining and quantifying the CCR5, CXCR4, dual/mixed coreceptor tropism. Recent data begun to emerge on how resistance develops with the accumulation of mutations in gp120 to maraviroc, the first-inclass R5 co-receptor antagonist.

Published: 11 May 2010

doi:10.1186/1742-4690-7-S1-120

Cite this article as: Ceccherini-Silberstein: Resistance to new

antiretrovirals (ETV, anti-integrases, entry inhibitors). Retrovirology 2010 7(Suppl 1):120.

\section{Submit your next manuscript to BioMed Central and take full advantage of: \\ - Convenient online submission \\ - Thorough peer review \\ - No space constraints or color figure charges \\ - Immediate publication on acceptance \\ - Inclusion in PubMed, CAS, Scopus and Google Scholar \\ - Research which is freely available for redistribution \\ Submit your manuscript at www.biomedcentral.com/submit}

